\title{
The Dynamics of Foreign Direct Investment in BRICS Countries
}

\author{
Kunofiwa Tsaurai \\ University of South Africa, Pretoria, South Africa \\ tsaurk@unisa.ac.za, kunofiwa.tsaurai@gmail.com
}

\begin{abstract}
Recent studies which investigated the determinants of foreign direct investment (FDI) in BRICS include Hsin-Hong and Shou-Ronne (2012), Nandi (2012), Jadhav (2012), Darzini and Amirmojahedi (2013), Nischith (2013), Ho et al. (2013), Kaur et al. (2013) and Priya and Archana (2014). The findings from these studies shows lack of consensus and confirm that a list of agreeable determinants of FDI in BRICS countries is still an unsettled matter. This paper was therefore initiated in order to contribute to the debate on the discourse on FDI determinants in BRICS countries.This paper deviates from earlier similar studies in five ways: (1) uses most recent data, (2) is the first to investigate whether a combination of financial development, trade openness, human capital, economic growth and inflation influence FDI in BRICS countries, (3) uses different proxies of the variables that affect FDI, (4) employed both fixed effects and pooled ordinary least squares (OLS) approaches and (5) used a stacked data approach.The results of the study showed that economic growth, trade openness and exchange rate stability positively impacted on FDI, financial development positively influenced FDI under fixed effects, FDI was positively influenced by human capital development using the pooled OLS and inflation negatively affected FDI in line with literature. Taking into account these findings, this study urges BRICS to implement policies that increase financial sector efficiency and economic growth, maintain stable exchange rates, keep inflation rates at lower levels, enhance trade openness and human capital development in order to increase FDI inflows.
\end{abstract}

Keywords: FDI; Determinants; Panel Study; BRICS

\section{Introduction}

According to Branco (2015), the expansion of the BRICS economies was slowed down by the end of the commodity super cycle, negative spill overs emanating from the financial crisis in developed countries and the inappropriate macro-economic policies that they adopted to respond to these two challenges. Following the eclectic paradigm theory of FDI which mentions that economic growth is a locational advantage of FDI, the slowdown in the growth of BRICS economies meant that they also gradually became unattractive foreign investment destinations.For China, the credit-inspired investment growth models which have been recently exhibiting signs of exhaustion could be one of the reasons for the slowdown in FDI inflows into China. From the World Bank (2015) data, this is supported by a 1.24 percentage points decline in FDI net inflow (\% of GDP) during the period from 2010 to 2014 in China (from 4.04\% of GDP in 2010 to $2.70 \%$ of GDP in 2014). Inefficient financial markets in China which had been characterised by negative real interest rates also played a major role in impeding FDI inflows into China, following Ezeoha and Cattaneo (2012).The deterioration of the macro-economic fundamentals and seemingly exhausted credit-inspired consumption growth model in Brazil are the two challenges at the centre of the slowdown in FDI inflows (Branco, 2015) in line with the output and market size hypothesis founded by Jorgenson (1963). Brazil experienced a budget deficit of $10.9 \%$ of GDP, inflation rates could not be contained within target levels and economic growth rate went down from 4.5\% between 2004 and 2010 to 1.5\% per annum between 2011 and 2014 (Branco, 2015:20). These factors, among others contributed to the deterioration of the macroeconomic environment, which according to the eclectic paradigm theory is a locational disadvantage of FDI inflow into Brazil.

On the other hand, the escalation of geopolitical disputes which led to Russia being put under sanctions by developed countries and the rent seeking activities involving the extortion of funds from both state enterprises and the private sector to the politically connected contributed to the slowdown in economic growth and FDI inflows in Russia (Branco, 2015:21). From the World Bank (2015) data, this is evidenced by a 1.60 percentage points decline in FDI net inflow (\% of GDP) during the period from 2010 to 2014 in Russia (from $2.83 \%$ of GDP in 2010 to $1.23 \%$ of GDP in 2014). According to Nandi (2012), factors such as administrative barriers, poor intellectual property rights enforcement and low quality of infrastructure were the key problems affecting FDI inflow into Russia. Another constraint according to Nandi (2012) has been that certain sectors of the Russia economy for example the banking sector have been allowed by the 
government to receive FDI only to a certain extent.The major stumbling block to FDI inflow into South Africa according to Branco (2015) has been the escalating protracted strikes and fight for improved wages that are completely disconnected to the productivity of the labour force. This argument is imbedded in the eclectic paradigm theory which also states that labour cost and the quality of labour are key determinants of FDI inflow into the host country. High poverty levels linked to the fact that 69\% (according to World Bank, 2014) of the population in India resides in rural areas reduces the market size and consequently FDI inflows, consistent with Jorgenson (1963)'s market size hypothesis.

It is evident that the challenges faced by the individual BRICS countries in terms of attracting FDI are not uniform and more so, there is no consensus with regard to a list of factors that influence FDI in BRICS countries.The ambiguity with regard to the determinants of FDI in BRICS countries can only be solved by carrying out additional empirical tests.It is for this reason that the current paper studied the determinants of FDI in BRICS countries. Recent studies which attempted to investigate the determinants of FDI in BRICS include Pao and Tsai (2011), Hsin-Hong and Shou-Ronne (2012), Nandi (2012),Jadhav (2012),Darzini and Amirmojahedi (2013),Nischith (2013),Ho et al. (2013), Kaur et al. (2013) and Priya and Archana (2014), among others. This study deviates from previous in the following ways: uses the most recent data available, is the first to investigate whether a combination of financial development, trade openness, human capital development, economic growth and inflation influence FDI in BRICS countries, this study uses different proxies of the variables that affect FDI, compares results of a fixed effects model and a pooled OLS panel data analysis and employed a stacked data panel regression approach.Findings from this study help BRICS authorities to develop and implement proper FDI promotion policies that scale up economic growth in the long run. Specifically, the results inform the BRICS policy makers on which absorption capacities must be put in place in order to trigger significant FDI inflows. The study is organized as follows: Section 2 discusses an empirical view of the determinants of FDI in BRICS, section 3 focus of FDI trends analysis in BRICS whereas section 4 investigates the determinants of FDI using an empirical model. Section 5 looks into the FDI inflow promotion policies in BRICS countries from an empirical literature review point and section 6summarizes the study.

\section{Literature Review}

FDI Determinants in BRICS Countries: Using regression analysis, a study by Hsin-Hong and Shou-Ronne (2012) revealed that low inflation rate and larger market size as represented by GDP significantly attracted FDI inflow into Brazil. The same study found out that trade openness had an insignificant positive impact on FDI inflow into Brazil. Previous studies which show high inflation rate as a deterrent to FDI inflows include the one done by Shamduddin (1994) and the other by Nath (2005). Nandi (2012) discovered that liberal reform policies such as financial markets liberalisation played a positive influential role in attracting FDI inflows into Brazil. A study by Vijayakumar et al. (2010) using panel data analysis discovered that larger market size, low labour cost, good infrastructure, stable currency and economy were the factors that significantly and positively attracted FDI inflow into BRICS countries. Just like in the study by Hsin-Hong and Shou-Ronne (2012), Vijayakumar et al. (2010) revealed that trade openness (the ratio of total trade to GDP) had a negligible impact on FDI inflow into the BRICS nations. Low labour costs, large consumer base and large production capacity were found by Nandi (2012) to be the critical factors that attracted FDI inflow into China. A study by Angelo et al. (2010) observed that exchange rates and country risk had an invisible influence on FDI inflow into Russia whilst low interest rates and high levels of consumer sales were the key factors that positively and significantly affected FDI location decisions in Brazil.

In a study using panel data analysis, Jadhav (2012) discovered that economic factors were more influential in attracting FDI into BRICS countries as compared to institutional and political factors. Market size as measured by real GDP was found by the same study to be the most influential factor in attracting FDI into BRICS countries whilst natural resources availability had a negative effect. Jadhav (2012) further noted a negative correlational relationship between rule of law and accountability versus FDI inflow into BRICS countries. This finding concurs with Cuervo-Cazura (2006) who showed that foreign investors from corrupt countries where anti-corruption laws are rarely enforced choose to operate in similar nations when they internationalise their operations. Although the quantity of FDI inflow was found to differ depending on the economic sector, Duan (2010) discovered that resources availability and good business environment had a significant positive 
impact on FDI inflows into BRIC (Brazil, Russia, India and China) countries. Lo and Liu (2009) noted that host country's industry-specific technological capabilities played a significant impact in determining the differences in quantity of FDI inflows received by India and China. China received more FDI inflows as compared to India due to superior industry-specific technological capabilities, argued Lo and Liu (2009).The level of macro-economic stability and socio political variables were found by Giner and Giner (2004) to have had an influential role in determining the quantity of FDI inflow into China and Russia. A study by Wei (1995) also revealed that the larger domestic consumer market in China was the main reason why China received a huge FDI inflow from OECD countries. The same study further highlighted that closer foreign trade relationship with OECD countries was also influential in attracting more FDI inflows into China from the OECD group of countries. Furthermore, the study by Wei (1995) suggested that apart from being in proximity to the OECD countries, lower labour cost and lower country risk accounted for a huge FDI inflow that was experienced by India not only from OECD countries but from other destinations as well.

Using Vector Error Correlation Model (VECM), Sridharan et al. (2009) discovered the existence of the feedback effect between economic growth and FDI inflows in three BRICS countries, namely Brazil, Russia and South Africa. The same study also reveals a uni-directional relationship running from FDI inflows to economic growth in India and China. A study by Pao and Tsai (2011) resonated with findings by Sridharan et al. (2009) by revealing that economic growth positively influenced FDI inflows into BRIC (Brazil, Russia, India and China) countries.The net rate of investment return and risk profile of FDI liabilities were discovered by Fedderke and Romm (2006) to be the main factors which determined FDI inflow into the South African economy. However, Zheng (2009) identified low labour costs, low political risk, high levels of GDP and liberalisation of the economic policy as factors that formed an integral part in attracting FDI inflows into both India and China. The same study noted that large consumer market size, and low cost of borrowing were particularly very crucial in attracting FDI inflow into Chia whilst low transaction costs played an influential role in determining FDI inflows into India. In addition, Darzini and Amirmojahedi (2013) found out that economic growth was influential in unlocking FDI inflows not only into BRIC countries but into Iran as well. Priya and Archana (2014) discovered that low political risk, low labour costs, high return on investment rates, high levels of economic liberalisation, size of the consumer market and flexible exchange rates were key main factors that attracted FDI inflows into the BRIC countries during the period 1991 to 2010. Nischith (2013) found out that stability of the local currency was instrumental in attracting FDI inflows into BRICS countries.

Using panel data analysis methodology, Ho et al. (2013) discovered that high economic growth, economic policy liberalisation, government expenditure, investment rate of return and trade openness positively impacted on FDI inflows into all the BRICS countries. The same study also revealed that economic liberalisation and infrastructural quality played a key role in attracting FDI inflows into BRICS nations. The impact of other factors on FDI inflows were more pronounced in other BRICS nations as compared to the others. For example, the same study by Ho et al. (2013) found out that high interest rates attracted FDI inflows into Brazil whilst discouraging FDI inflows into other BRICS countries. The size of the consumer market was discovered to have influenced FDI into Russia, China and Malaysia whilst it had no impact on FDI inflow into India and South Africa (Muneer \& Rehman, 2012; Ho et al., 2013). Level of financial market development had a significant positive impact on FDI inflows in all other BRICS countries except in Russia, revealed Ho et al. (2013).Kaur et al. (2013) revealed that banking sector and stock market development variables played a crucial role in attracting FDI into BRIC (Brazil, Russia, India and China) countries. More specifically, a larger banking sector size and higher stock market capitalisation were discovered to have positively influenced FFDI into BRIC nations. The same study however found out the existence of a negative relationship between domestic credit by banking sector and FDI inflow into BRIC nations understandably because the need for foreign capital decreases as domestic capital availability increases. In a study for the period between 1986 to 1998, Sun et al. (2002) discovered that high labour quality and good infrastructure positively influenced FDI inflows into the 30 Chinese provinces. Political stability and trade openness were more instrumental in deciding the quantum of FDI inflows into the Chinese economy as a whole, revealed Sun et al. (2002).

Pan (2003) discovered that the strength of the local currency (Yen) played a negligible role in influencing positive FDI inflows into China from different source countries. Contrary to other previous studies, low 
country risk profile did very little to trigger FDI inflows into China, revealed Pan (2003). The same study observed that proximity between China and source countries played a huge positive impact on FDI inflows into China. According to Fung et al (2005), more FDI from United States of America (USA), Japan, Hong Kong, Taiwan and Korea was attracted into China mainly by transparent institutions and high level of market reforms. The same study showed that hard infrastructure such as the state of the roads and railway lines had a negligible impact on FDI inflow into China. However, Canfei (2006) discovered that Chinese provinces with greater autonomy in economic decision making processes and tight fiscal budget managed to attract more FDI. High level of government economic participation and more government legal spending in the Chinese provinces chased away FDI, revealed Canfei (2006). According to Iwasaki and Suganuma (2007), the extent of natural resources endowment, consumer market size and economic growth played a huge role in influencing the distribution of FDI inflows across all the regions in Russia. Specifically, Russia regions which had more natural resources, higher consumer market size and better economic growth attracted more FDI, revealed Iwasaki and Suganuma (2007). Ali and Guo (2005) revealed that consumer market size played an influential role in attracting FDI into China from USA firms whilst low labour cost positively influenced FDI into China from other Asian firms. However, high investment rate of return was revealed by the same study to have attracted FDI from both USA and Asian firms into China.

An Empirical Perspective of FDI Promotion Policies in BRICS: Hsin-Hong and Shou-Ronne (2012) argued that Brazil could attract more FDI by boosting its GDP (market size). Increasing government expenditures lead to increased aggregate demand, consumption and GDP levels and that in turn attract FDI inflow into Brazil (Hsin-Hong and Shou-Ronne, 2012; Lubis et al., 2015). The same study also suggested that Brazil should maintain a tight monetary policy that keep inflation rates at lower levels in order to stimulate increased FDI inflows into the country. This policy recommendation agrees with the findings by Bengoa and Sanchez-Robles (2003).Vijayakumar et al. (2010) noted that policies aimed at stabilising BRICS's local currencies needed to be put in place and strengthened in order to attract more FDI inflow. The same study suggested that economic reform and liberalisation policies in BRICS countries needed to be accelerated to enable more FDI inflows.According to the consolidated FDI policy (2014), the government of India designed measures to make it easy for FDI to flow into the country and these include the automatic route and government route policy of FDI. The automatic route policy stipulates that non-resident investor does not require pre-approval from the Indian government whilst the government route requires that government approves the non-resident investor first before investing in certain sectors of the economy (consolidated FDI policy, 2014).

According to Nandi (2012), the dropping of protectionist policies in favour of FDI inflow friendly policies in the 1990s by Brazil led it to become arguably one of the largest FDI destinations in the world. The same study pointed out that the reformed FDI policies implemented since early 1990s has led China to be largest beneficiary of FDI inflows among the emerging economies in the last two decades. China made it easy for potential foreign investors to see which sectors of the economy are there more and brighter prospects through their guiding directory, argued Nandi (2012). Angelo et al. (2010) suggested that policies that stimulate consumer demand works better in attracting FDI inflows as compared to the fiscal and monetary policies for a larger emerging market such as Brazil. Fedderke and Romm (2006) recommended that South African authorities should reduce political risk, increase GDP (market size), lower down corporate tax and ensure property rights are respected in order to attract more FDI inflow. Integrating South African economy into the world economy not only attracts more FDI inflows but ensure that South Africa benefits maximally from the foreign capital, argued Fedderke and Romm (2006). Moreover, Zheng (2009) encouraged Chinese authorities to maintain economic, political and policy stability in order to continue attracting more FDI inflows. The whole economy of China and India should be opened up to FDI, property rights respected and corruption index reduced in order to create an attractive FDI climate, argued Zheng (2009). India should adopt an export-led growth strategy if it was to accelerate FDI inflows into its economy (Zheng, 2009).

Ali and Guo (2005) recommended that China should accelerate its economic and political reform policies in order to gain not only increased FDI inflows but to enable FDI benefits to successfully permeate throughout the whole economy. In order to narrow the huge gap of development among the Southern, Western and Eastern regions, Ali and Guo (2005) urged China to invest more into infrastructural and human capital development policies that will attract more FDI inflows. Moreover, Kamath (2008) encouraged the Indian 
government to implement policies aimed at improving employer-employee relations, financial market reforms and economic policy consistency in order to attract more FDI inflow. Darzini and Amirmojahedi (2013) urged BRICS countries to develop their financial markets in order to boost FDI inflows and economic growth beneficiation.The same study showed that high level of financial markets development attracted FDI inflow into BRICS countries as foreign investors were more interested in the economy that efficiently allocates financial resources. Ho et al. (2013) suggested that policies aimed at stimulating financial development and economic policy liberalisation needed to be accelerated in order to attract more FDI inflows into BRICS countries. On the other hand, Kaur et al. (2013) recommended that BRIC authorities should formulate and implement policies that ensure both banking sector and stock markets are efficient in order to attract more FDI inflows.

FDI Trend Analysis in BRICS Countries: Due to the fact that BRIC countries have attracted much of the world's FDI and become more important in the global market, it is reasonable to know the overall trends of FDI inflows into BRICS countries (Duan, 2010).

FDI net inflow trends in BRICS countries (United States Billion Dollars): According to World Bank (2015) statistics, FDI net inflows went up by $276.08 \%(U S \$ 1.29$ billion in 1993 to US $\$ 4.86$ billion in 1995) in Brazil, 70.52\%(US $\$ 1.21$ billion in 1993 to US $\$ 2.07$ billion in 1995) in Russia, 289.49\%(US\$0.55 billion in 1993 to US\$2.14 billion in 1995) in India, 30.29\%(US\$27.52 billion in 1993 to US\$35.85 billion in 1995) in China and 10 957\%(US\$0.01 billion in 1993 to US\$1.25 billion in 1995) in South Africa - see Figure 1.However, the five year period between 1995 and 2000 saw FDI net inflows going up from US $\$ 4.86$ billion to US $\$ 32.78$ billion in Brazil, from US $\$ 2.14$ billion to US $\$ 3.58$ billion in India, from US $\$ 2.07$ billion to US $\$ 2.71$ billion in Russia and from US $\$ 35.85$ billion to US\$38.40 billion in China. On the contrary, FDI net inflows recorded a negative growth during the same time period (from US $\$ 1.25$ billion to US $\$ 0.97$ billion) in South Africa.In Brazil, FDI net inflows declined by $52.84 \%$ (from US $\$ 32.78$ billion in 2000 to US $\$ 15.46$ billion in 2005), positively grew by $245.05 \%$ to close the year 2010 at US $\$ 53.34$ billion before recording an increase of $51.55 \%$ (US $\$ 53.34$ billion in 2010 to US $\$ 80.84$ billion in 2013). FDI net inflows consistently continued on an upward trend from 2005 to 2013 in Russia. It went up by $471.36 \%$ (from US $\$ 2.71$ billion in 2000 to US $\$ 15.51$ billion in 2005, 178.36\% to close the year 2010 at US\$43.17 billion before recording a further $63.67 \%$ growth between 2010 and 2013 in Russia.

India also experienced positive growth of FDI net inflows between 2000 and 2013. Between 2000 and 2005, FDI net inflows grew by $102.82 \%$ before further increasing by a massive $276.88 \%$, from US $\$ 7.27$ billion in 2005 to US $\$ 27.40$ billion in 2010 . The period between 2010 and 2013 saw FDI net inflows going marginally up by $2.76 \%$ to close the year 2013 at US $\$ 28.15$ billion. On the other hand, FDI net inflows in China increased by $189.62 \%$ between 2000 and 2005, further grew by $145.47 \%$ between 2005 and 2010 before further recording another growth by $27.42 \%$ (from US $\$ 272.99$ billion in 2010 to US $\$ 347.85$ billion in 2013). However, South Africa was characterised by FDI net inflow growth of $573.19 \%$ (from US $\$ 0.97$ billion in 2000 to US $\$ 6.52$ billion in 2005) before experiencing a $43.37 \%$ negative growth to end the year 2010 at US\$3.69 billion. The subsequent three year period saw FDI net inflow going up by $119.81 \%$ to end the year 2013 at US\$8.12 billion.

According to Figure 2, China received the most net FDI inflows during the period 1993 to 2013, followed by Brazil (US\$644.15 billion), then Russia (US $\$ 489.64$ billion), India (US $\$ 286.81$ billion) and lastly South Africa (US\$71.34 billion). There is a clear uneven distribution of net FDI inflow into BRICS countries with China having received $63 \%$, Brazil 16\%, Russia $12 \%$, India $7 \%$ and South Africa $2 \%$. This raises the question as to whether countries such as India and South Africa benefit much by being part of the BRICS economic group. The fact that South Africa only recently joined BRICS could help to partly explain why the country's FDI net inflows is negligible in comparison to other BRICS countries. 
Figure 1: FDI net inflows (US\$ Billions) trends for BRICS countries (1993-2013)

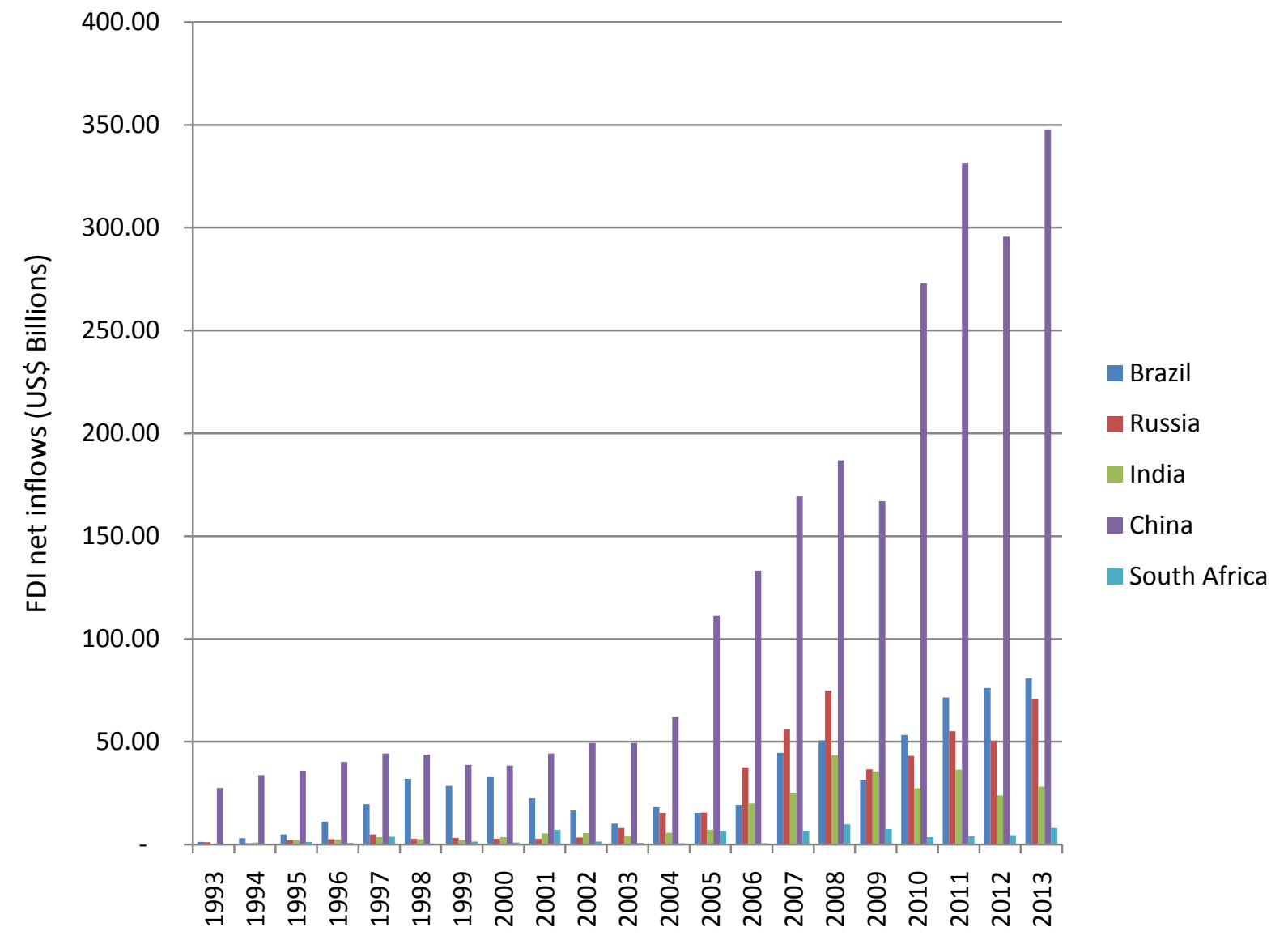

Source: World Bank (2015)

Figure 2: Total FDI net inflows received by BRICS countries from 1993 to 2013 (US\$ billions)

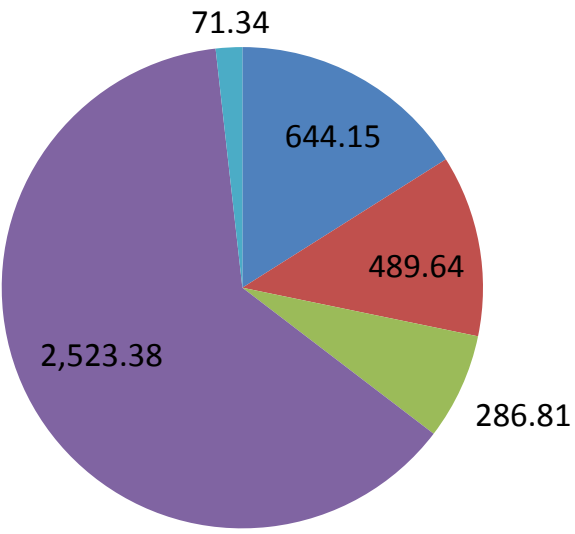

Brazil
Russia
India
China
South Africa

Source: World Bank (2015) 
FDI net inflow (as a share of GDP) trends in BRICS countries: World Bank (2015) statistics shows that FDI net inflow as a share of GDP in BRICS nations is characterised by both positive and negative trends during the period from 1994 to 2014 (see Figure 3 and 4).

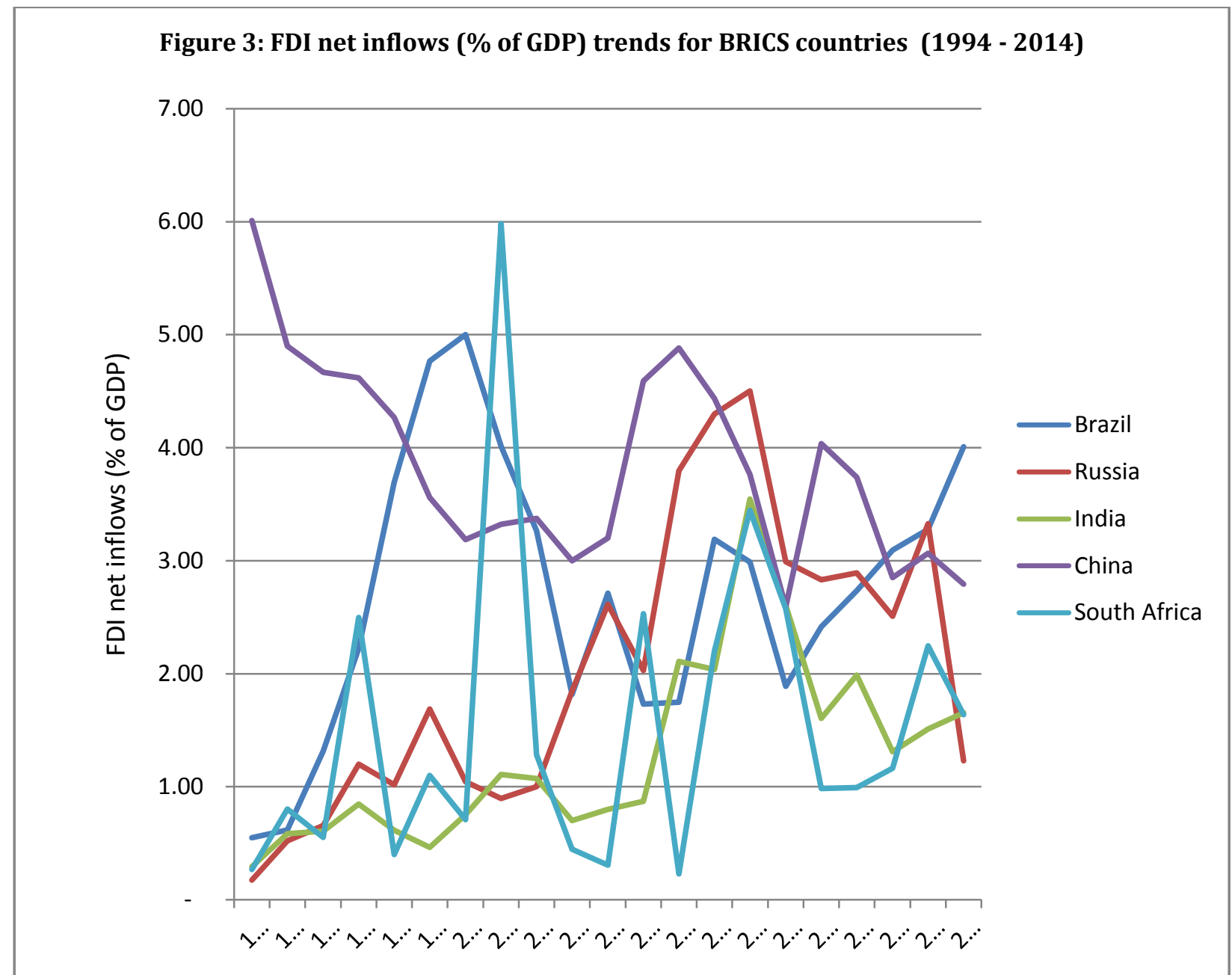

Source: World Bank (2015)

Russia, India and South Africa recorded the highest positive growth in FDI net inflow (\% of GDP) between 1994 and 1995 whilst net FDI inflow (\% of GDP) into China experienced a negative growth by 1.11 percentage points. The five year period between 1995 and 2000 saw Brazil recording a positive growth of 4.38 percentage points in net FDI net inflow (\% of GDP), followed by Russia ( 0.52 percentage points) and then India ( 0.17 percentage points). China and South Africa experienced a negative growth in net FDI inflow (\% of GDP) of 1.71 and 0.09 percentage points respectively during the same time period. South Africa experienced a huge net FDI inflow (\% of GDP) positive growth of 1.82 percentage points, followed by China (1.40 percentage points), Russia ( 0.98 percentage points) and then India ( 0.12 percentage points) during the period from 2000 to 2005. The same time frame saw Brazil's net FDI inflow (\% of GDP) declining by 3.27 percentage points, from 5\% in 2000 to $1.73 \%$ in 2005.The subsequent five yearperiod saw Brazil, Russia and India recording positive growth in net FDI inflow as a share of GDP of $0.68,0.80$ and 0.73 percentage points respectively whilst China and South Africa were characterised by negative growth in net FDI inflow (\% of GDP) of 0.55 and 1.55 percentage points respectively during the same time frame. Last but not least, Brazil, India and South Africa recorded positive growth in net FDI inflow (\% of GDP) whilst Russia and China's net FDI inflow (\% of GD) negatively grew during the period from 2010 to 2014. Overall, Brazil experienced the highest increase in net FDI net inflow (\% of GDP) of 3.46 percentage points, followed by South Africa (1.37 percentage points), India (1.36 percentage points) and then Russia (1.06 percentage points) during the 
period from 1994 to 2014. China is the only BRICS country whose net FDI inflow (\% of GD) declined during the period under study, from $6.01 \%$ in 1994 to $2.79 \%$ in 2014 (World Bank, 2015 statistics). It is the author's view that the uneven and fluctuating FDI inflow statistics which characterised the BRICS countries during the period under study provide a reason why the FDI determinants in BRICS need to be investigated.

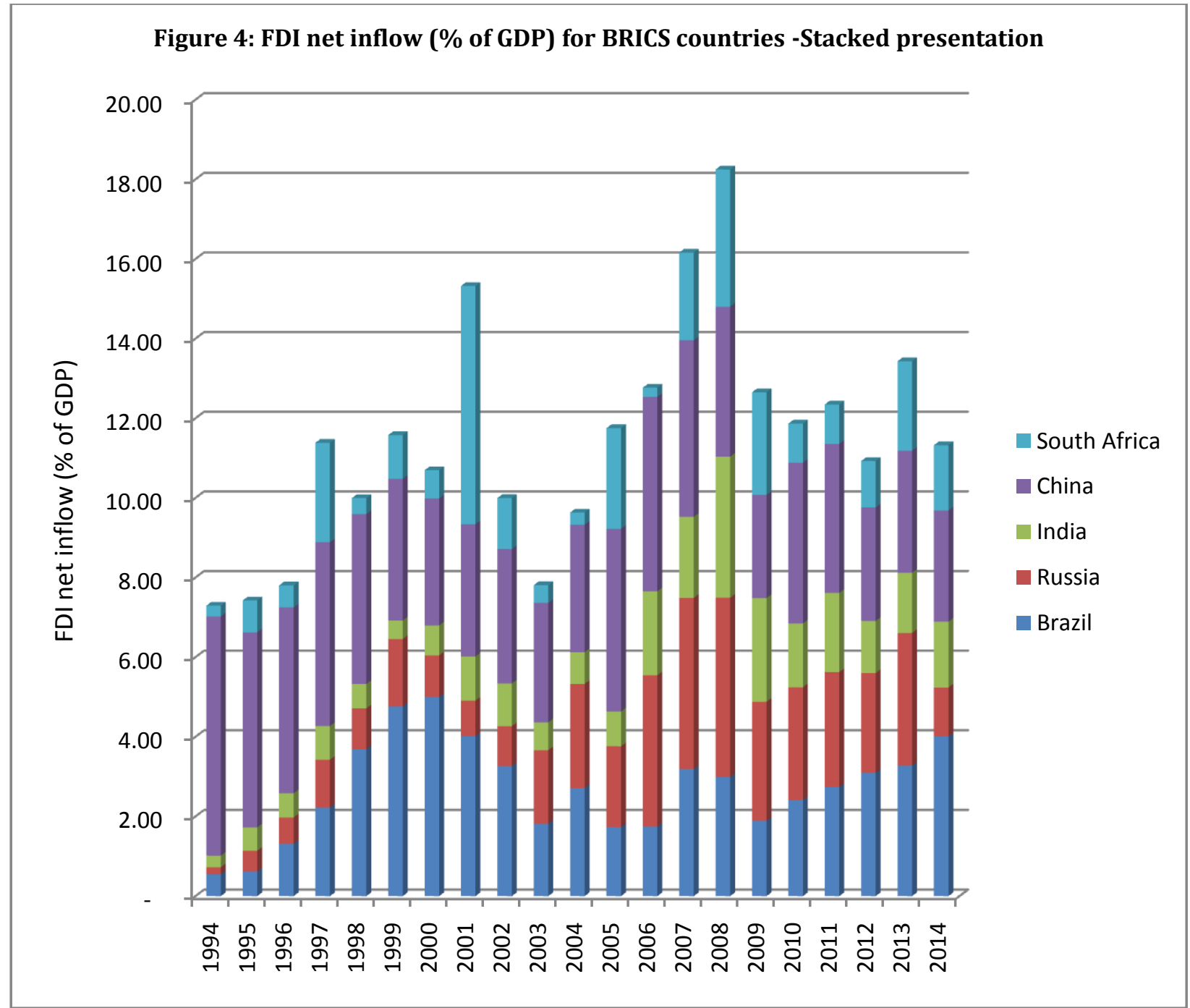

Source: World Bank (2015)

\section{Investigating FDI Determinants in BRICS Using an Empirical Model}

The major determinants of FDI as derived from literature are summarised by the following general model specification.

FDI = $\mathrm{f}(\mathrm{FIN}, \mathrm{GROWTH}, \mathrm{INF}, \mathrm{EXCH}$, OPEN, HUM $)$

Where FDI is foreign direct investment, GROWTH represents economic growth, FIN is financial development and INF stands for inflation. EXCH represents exchange rates, OPEN is trade openness whilst HUM represents human capital development.The choice of the independent variables and their proxies was guided by the empirical studies on similar research work (Pan. 2003; Kaur et al. 2013; Sridharan et al. 2009; Giner and Giner. 2004; Vijayakumar et al. 2010; Branco. 2015). FIN is proxied by stock market capitalisation as a ratio of GDP, GROWTH is measured by GDP per capita whilst EXCH is proxied by exchange rate (local currency/US\$). OPEN is measured by total exports and imports of goods and services (\% of GDP) and the proxy for HUM is the human capital development index. 
The data used for the purpose of this study was obtained from World Development Indicators, international financial statistics, international monetary fund, African Development Indicators Global Financial Indicators and United Nations Development Programme several reports. According to Nnadi and Soobaroyen (2015), the risk of discrepant data and bias is dealt away with since the sources of data used are all in the domain of the public.Following literature ((Pan. 2003; Kaur et al., 2013; Sridharan et al., 2009; Giner and Giner. 2004; Vijayakumar et al., 2010; Branco, 2015), financial development, economic growth, trade openness and human capital development is anticipated to positively affect FDI. On the other hand, inflation is expected to negatively affect FDI (Hsin-Hong and Shou-Ronne, 2012; Branco, 2015; Bengoa and Sanchez-Robles, 2003) whilst a weak currency in the host country is anticipated to positively attract more FDI (Vijayakumar et al., 2010; Nischith, 2013).

Table 1: Descriptive statistics

\begin{tabular}{llllllll}
\hline & FDI & FIN & GROWTH & INF & EXCH & OPEN & HUM \\
\hline Mean & 2.29 & 75.43 & 4273 & 33.48 & 17.03 & 43.17 & 0.69 \\
Median & 2.20 & 45.34 & 3288 & 6.64 & 8.28 & 46.85 & 0.71 \\
Maximum & 6.01 & 276.60 & 14487 & 2075 & 61.03 & 72.87 & 0.82 \\
Minimum & 0.17 & 0.04 & 353 & 0.26 & 0.66 & 15.64 & 0.45 \\
Standard dev. & 1.45 & 69.57 & 3654 & 204.45 & 16.83 & 14.84 & 0.08 \\
Skewness & 0.44 & 1.46 & 1.10 & 9.66 & 0.93 & -0.23 & -0.65 \\
Kurtosis & 2.31 & 4.13 & 3.42 & 96.72 & 2.44 & 1.88 & 2.61 \\
Jarque-Bera & 5.47 & 42.69 & 22.02 & 40062 & 16.39 & 6.42 & 8.14 \\
Probability & 0.06 & 0.00 & 0.00 & 0.00 & 0.00 & 0.04 & 0.02 \\
\hline
\end{tabular}

Source: Author compilation from E-Views (8)

FIN, GROWTH, INF, EXCH AND OPEN are characterised with very high standard deviation from the mean whilst the high range values for all the variables shows the presence of extreme values or outliers. The Kurtosis figures shows that all the variables used in this study are skewed to the right, a sign of the absence of a normal distribution. The Jarque-Bera statistics shows that the data for FDI, FIN, GROWTH, INF, EXCH, OPEN and HUM does not follow a normal distribution. It is against this backdrop that this paper converted the data sets for all variables into natural logarithms in order to make it suitable for econometric analysis, in line with Odhiambo (2008) who argued that normality of datasets is a pre-requisite in econometric modelling. Consistent with Nobakht and Madani (2014), converting the data into natural logarithms ensures that both auto-correlation bias and the impact of abnormal data values are dealt away with.

Table 2: Correlation analysis

\begin{tabular}{llllllll}
\hline & FDI & FIN & GROWTH & INF & EXCH & OPEN & HUM \\
\hline FDI & 1.000 & & & & & & \\
FIN & -0.2137 & 1.000 & & & & & \\
GROWTH & $0.1626^{*}$ & $0.1741^{*}$ & 1.000 & & & & \\
INF & -0.1580 & -0.0918 & -0.0369 & 1.000 & & \\
EXCH & -0.2705 & -0.1617 & -0.2661 & -0.1119 & 1.000 & & \\
OPEN & 0.0191 & $0.4289^{* * *}$ & 0.0369 & -0.1359 & 0.1201 & 1.000 & \\
HUM & $0.2534^{* * *}$ & -0.1847 & $0.4641^{* * *}$ & 0.1317 & -0.5253 & 0.0937 & 1.000 \\
\hline
\end{tabular}

Source: Author compilation from E-Views (8)

$* * *$ and ${ }^{*}$ indicate $1 \%$ and $10 \%$ significance levels respectively

Descriptive statistics describes the nature of the data whilst correlation matrix shows the direction and the nature of association between all the variables used in this study (see Table 2). As expected, GROWTH, OPEN and HUM are positively correlated with FDI whilst a negative association between INF and FDI was also observed. Contrary to literature, FIN is negatively correlated with FDI. Moreover, GROWTH and OPEN are positively associated with FDI whilst INF as expected was negatively correlated with FDI. In contrast to theory, EXCH and HUM are negatively associated with FDI.OPEN and HUM are positively correlated with GROWTH whilst INF and FDI is negatively associated as expected and contrary to literature, EXCH is negatively correlated with FDI.Majority of the correlations between the variables under study are in sync 
with the dictates of the literature.In Table 2, all the correlational relationship are below 53\%. According to Stead (1996), this means the challenge of multicollinearity does not exist.

Empirical model specification: This paper used the following empirical model to test the determinants of FDI in BRICS countries.

$\mathrm{FDI}_{\mathrm{it}}=\alpha_{\mathrm{i}}+\beta_{1} \mathrm{FIN}_{\mathrm{it}}+\beta_{2} \mathrm{GROWTH}_{\mathrm{it}}+\beta_{3} \mathrm{INF}_{\mathrm{it}}+\beta_{4} \mathrm{EXCH}_{\mathrm{it}}+\beta_{5} \mathrm{OPEN}_{\mathrm{it}}+\beta_{6} \mathrm{HUM}_{\mathrm{it}}+\operatorname{Eit}[2]$

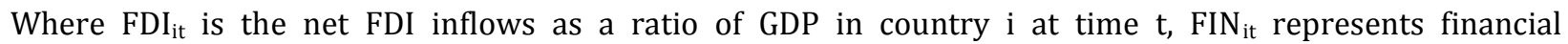
development in country i at time $\mathrm{t}, \mathrm{GROWTH}_{\text {it }}$ is gross domestic product, $\mathrm{INF}_{\mathrm{it}}$ stands for inflation in country $\mathrm{i}$ at time $t, \mathrm{EXCH}_{\mathrm{it}}$ represents exchange rates in country i at time $\mathrm{t}, \mathrm{OPEN}_{\mathrm{it}}$ is trade openness in country $\mathrm{i}$ at time t whilst $\mathrm{HUM}_{\mathrm{it}}$ represents human capital development in country i at time t.Eitis the error term and $\alpha_{\mathrm{i}}$ is the intercept. $\beta_{1}$ and $\beta_{2}$ up to $\beta_{2}$ are the coefficients of the independent variables.

\section{Results and Interpretation}

Panel data analysis was used to investigate the determinants of FDI for BRICS countries with annual data ranging from 1994 to 2014. Employing stacked panel data approach, this study found out results contained in Table 3.

Table 3: Panel regression results for FDI

\begin{tabular}{|c|c|c|c|c|}
\hline \multirow[t]{2}{*}{ Variable } & \multicolumn{4}{|c|}{ Dependent variable: FDI } \\
\hline & Co-efficient & t-statistic & Co-efficient & t-statistic \\
\hline GROWTH & 0.1117 & 1.1122 & 0.0721 & 0.6630 \\
\hline HUM & -0.6024 & -0.6432 & $2.0249^{* *}$ & 2.3894 \\
\hline INF & -0.0381 & -0.5362 & -0.3343 & -4.7433 \\
\hline FIN & 0.0568 & 0.6596 & -0.0683 & -0.8301 \\
\hline OPEN & $0.5793^{* *}$ & 2.0463 & 0.0006 & 0.0025 \\
\hline EXCH & $0.6120^{* * *}$ & 3.3742 & 0.0378 & 0.4234 \\
\hline $\mathrm{C}$ & -4.2106 & -3.7208 & 1.5866 & 1.3812 \\
\hline & R-squared & 0.6062 & R-squared & 0.2617 \\
\hline & Adjusted R-squared & 0.5643 & Adjusted R-squared & 0.2165 \\
\hline & F-statistic & 14.4698 & F-statistic & 5.7893 \\
\hline & Prob (F-statistic) & 0.0000 & Prob (F-statistic) & 0.0000 \\
\hline
\end{tabular}

Source: Author compilation from E-Views (8)

*** and ${ }^{* *}$ indicate $1 \%$ and $5 \%$ significance levels respectively

According to Table 3, economic growth positively but non significantly influenced FDI whilst the opposite was true in the case for inflation rate and FDI nexus under both fixed effects and pooled OLS panel regression approaches. Moreover, high levels of trade openness and exchange rate stability positively and significantly impacted on FDI under the fixed effects panel regression estimation technique whereas the same variables positively but non-significantly affected FDI in the pooled OLS panel regression framework. These results concur with literature.Whilst human capital development positively and significantly influenced FDI under the pooled OLS panel method in line with the literature, the fixed effects approach shows that human capital development negatively affected FDI. A scenario where high human capital development levels increases the cost of labour can end up acting as an FDI locational disadvantage. Financial development as measured by stock market capitalisation ratio had a positive and a non-significant impact on FDI under the fixed effects in consistent with literature. On the other hand, financial development negatively affected FDI in the pooled OLS panel regression approach. The possible explanation is that the financial markets in BRICS were inefficient during the period under study in line with Ezeoha and Cattaneo (2012) whose study observed that inefficient financial markets in China which were characterised by negative real interest rates stifled the flow of FDI into China. The finding also resonates with Kaur et al. (2013) whose study found out that domestic credit by banking sector negatively influenced FDI flow into BRICS countries. 


\section{Conclusion}

The major aim of this study was to investigate the determinants of FDI in BRICS countries. The study also discussed the various factors which determined FDI in BRICS countries from both a theoretical and empirical point of view. Recent trends indicate increased FDI outflow from BRICS countries or reduced FDI inflow into BRICS countries (see section 3). The possible reasons for such FDI net inflow trends in recent years in BRICS countries have also been unpacked.The study discussed some of the challenges facing FDI inflows as well as policies that could be implemented to rejuvenate FDI inflows in BRICS countries.The investigation of FDI determinants using an econometric empirical model (see equation 2) produced the following findings for BRICS: (1) both fixed effects and pooled OLS approaches show that economic growth, trade openness and exchange rate stability had a positive impact on FDI, (2) financial development positively influenced FDI under the fixed effects approach, (3) FDI was positively influenced by human capital development using the pooled OLS and (4) inflation negatively affected FDI under both panel data analysis methods in line with literature.Taking into account these findings and the ongoing debate on the dynamics of FDI, several policy mix implications are applicable to BRICS countries.This study urges BRICS countries to implement policies and programmes that increase the efficiency of the financial sector, economic growth, maintain stable exchange rates, enhance trade openness and human capital development in order to trigger significant FDI inflows.A tight monetary policy that keep inflation rates at lower levels and ensure exchange rates stability should be put in place in order to attract more FDI inflow into BRICS countries.Subject to availability of data, the author suggests that future studies should empirically examine the applicability to BRICS of all the determinants of FDI mentioned in the literature review. Such a study can be done using generalised methods of moments (GMM), an econometric approach which addresses the endogeneity problem.

\section{References}

Ali, S. \& Guo, W. (2005). Determinants of FDI in China.Journal of Global Business and Technology, 1(2), 21-33.

Angelo, C.F.D.,Eunni, R.V. \& Fouto, N.M.M.D. (2010). Determinants of FDI in emerging markets: Evidence from Brazil. International Journal of Commerce and Management, 20(3), 203-216.

Bengoa, M. \&Sanchez-Robles, B. (2003).Foreign direct investment, economic freedom and growth: New evidence from Latin America.European Journal of Political Economy,19(3), 529-545.

Branco, R.C. (2015). The BRICS: Some historical experiences, growth challenges and opportunities. Fundacao Getulio Vargas, Centre for Growth and Economic Development, 1-26.

Canfei, H. (2006). Regional decentralisation and location of foreign direct investment in China. PostCommunist Economies, 18(1), 32-50.

Consolidated FDI policy. (2014). Department of Industrial Policy and Promotion. Ministry of Commerce and Industry Government of India. Circular 1 of 2014. 1-118.

Cuervo-Cazurra, A. (2006). Who cares about corruption? Journal of International Business Studies, 37(6), 807822.

Darzini, B.F. \&Amirmojahedi, S. (2013). The impact of foreign direct investment on economic growth in BRIC countries and in comparison with Iran. Advances in Environmental Biology, 7(8), 1970-1978.

Duan, Y. (2010). FDI in BRICS: a sector level analysis. International Journal of Business and Management, 15(1), 46-52.

Ezeoha, A.E. \& Cattaneo, N. (2012). FDI flows to Sub-Saharan Africa: The impact of finance, institutions and natural resource endowment. Comparative Economic Studies, 54(3), 597-632.

Fedderke, J.W. \& Romm, A.T. (2006). Growth impact and determinants of foreign direct investment into South Africa. Economic Modelling, 23(5), 738-760.

Fung, K.C., Herrero, A.G., Iizaka, H. \& Siu, A. (2005). Hard or soft? Institutional reforms and infrastructure spending as determinants of foreign direct investment in China.The Japanese Economic Review, 56(4), 408-416.

Giner, J.M. \& Giner, G. (2004). An interpretative model of foreign direct investment in China: An economic policy approach. China Economic Review, 15(3), 268-280.

Ho, C.S.F., Ahmad, N. \& Dahan, H.M. (2013). Economic freedom, macroeconomic fundamentals and foreign direct investment in fast emerging BRICS and Malaysia. International Journal of Banking and Finance, 10(1), 1-17. 
Hsin-Hong, K. \&Shou-Ronne, H. (2012). An analysis of the determinants of inward direct investment in Brazil. Proceedings of ASBBS, 19(1), 472-487.

Iwasaki, I. \&Suganuma, K. (2007). Regional distribution of foreign direct investment in Russia. PostCommunist Economies, 17(2), 153-172.

Jadhav, P. (2012). Determinants of foreign direct investment in BRICS economies: Analysis of economic, institutional and political factor. Procedia-Social and Behavioral Sciences, 37(December), 5-14.

Jorgenson, D.W. (1963). Capital theory and investment behaviour. The American Economic Review, 53(2), 247259.

Kamath, G.B. (2008). Impact of foreign direct investment in India. The Icfai University Journal of International Business, 3(4), 16-38.

Kaur, M., Yadav, S.S. \& Gautam, V. (2013). Financial system development and foreign direct investment: A panel data study for BRIC countries. Global Business Review, 14(4), 729-742.

Lo, C.\& Lui, B.J. (2009). Why India is mainly engaged in offshore service activities, while China is disproportionately engaged in manufacturing? China Economic Review, 20(2), 236-245.

Lubis, H., Kumar, M. D., Ikbar, P. \& Muneer, S. (2015).Role of Psychological Factors in Individuals Investment Decisions. International Journal of Economics and Financial Issues, 5(Special Issue).

Muneer, S. \& Rehman, S. U. (2012). Materialization of Behavioral Finance and Behavioral Portfolio Theory: A Brief Review. Journal of Economics and Behavioral Studies, 4(8), 431-435

Nandi, S. (2012). Comparative analysis of foreign direct investment trends in emerging economies. ProcediaSocial and Behavioral Sciences, 37, 230-240.

Nath, H. (2005). Trade, Foreign direct investment and growth: Evidence from transition economies. SHSU Economics and International Business Working paper No. SHSU-Eco-WP05-04. Huntsville, TX: Sam Houston State University.

Nischith, S. (2013). Impact of exchange rate volatility on foreign direct investment: A case of BRICS. Zenith International Journal of Business Economics and Management Research, 3(4), 260-269.

Nobakht, M. \&Madani, S. (2014). Is FDI spill-over conditioned on financial development and trade liberalisation: Evidence from UMCs. Journal of Business and Management Sciences, 2(2), 26-34.

Nnandi, M. \& Soobaroyen, T. (2015). International financial reporting standards and foreign direct investment: The case of Africa. Advances in accounting, 31(2), 228-238.

Odhiambo, N. M. (2008). Financial depth, savings and economic growth in Kenya: A Dynamic causal linkage.Economic Modelling, 25(4), 704-13.

Pan, Y. (2003). The inflow of foreign direct investment to China: The impact of country specific factors. Journal of Business Research, 56(10), 829-833.

Pao, H.T. \& Tsai, C.M. (2011). Multivariate granger causality between CO2 emissions, energy consumption, FDI and GDP: Evidence from a panel of BRIC (Brazil, Russia, India and China) countries. Energy, 36(1), 685-693.

Priya, G. \&Archana, S. (2014). Macro-economic determinants of foreign direct investment in BRIC nations. South Asian Journal of Marketing and Management Research, 4(2), 1-12.

Shamsuddin, A.F.M. (1994).Economic determinant of foreign direct investment in less developing countries. The Pakistan Development Review, 33(1), 41-51.

Sridharan, P., Vijayakumar, N. \& Chandra, S.R.K. (2009). Causal relationship between foreign direct investment and growth: Evidence from BRICS countries. International Business Research, 2(4), 198203.

Stead, R. (1996). Foundation quantitative methods for business. Prentice Hall. England.

Sun, Q., Tong, W. \& Yu, Q. (2002). Determinants of foreign direct investment across China. Journal of International Money and Finance, 21(1), 79-113.

Vijayakumar, N., Sridharan, P. \& Rao, K.C.S. (2010). Determinants of FDI in BRICS countries: A panel data analysis. International Journal of Business. Science and Applied Management, 5(3), 1-13.

Wei, S.J. (1995). Attracting foreign direct investment: Has China reached its potential? China Economic Review, 6(2), 187-199.

World Bank. (September 2014). Implications of a changing China for Brazil: A new window of opportunity?

World Bank. (2015). World Development Indicators published by the World Bank, Washington D.C.

Zheng, P. (2009). A comparison of FDI determinants in China and India.Thunderbird International Business Review, 51(3), 263-279. 